\title{
Fatty acid metabolism in breast cancer subtypes
}

\author{
Marie E. Monaco ${ }^{1,2}$ \\ ${ }^{1}$ Department of Neuroscience \& Physiology, New York University School of Medicine, New York, NY, USA \\ ${ }^{2}$ Veterans Affairs New York Harbor Healthcare System, New York, NY, USA \\ Correspondence to: Marie E. Monaco, email: mem6@nyu.edu \\ Keywords: fatty acid metabolism, molecular subtype, breast cancer \\ Received: October 19, $2016 \quad$ Accepted: February 06, $2017 \quad$ Published: February 18, 2017 \\ Copyright: Monaco et al. This is an open-access article distributed under the terms of the Creative Commons Attribution License (CC-BY), \\ which permits unrestricted use, distribution, and reproduction in any medium, provided the original author and source are credited.
}

\section{ABSTRACT}

Dysregulation of fatty acid metabolism is recognized as a component of malignant transformation in many different cancers, including breast; yet the potential for targeting this pathway for prevention and/or treatment of cancer remains unrealized. Evidence indicates that proteins involved in both synthesis and oxidation of fatty acids play a pivotal role in the proliferation, migration and invasion of breast cancer cells. The following essay summarizes data implicating specific fatty acid metabolic enzymes in the genesis and progression of breast cancer, and further categorizes the relevance of specific metabolic pathways to individual intrinsic molecular subtypes of breast cancer. Based on mRNA expression data, the less aggressive luminal subtypes appear to rely on a balance between de novo fatty acid synthesis and oxidation as sources for both biomass and energy requirements, while basal-like, receptor negative subtypes overexpress genes involved in the utilization of exogenous fatty acids. With these differences in mind, treatments may need to be tailored to individual subtypes.

\section{INTRODUCTION}

Fatty acid metabolism (FAM) comprises a variety of pathways including fatty acid transport, de novo synthesis, activation, incorporation into neutral and polar glycerides, storage as triglyceride and cholesterol esters in lipid droplets, mobilization from phospholipids and triglycerides, oxidation and, in the case of arachidonic acid, conversion to eicosanoids such as prostaglandins and leukotrienes. The malignant phenotype is characterized by alterations in these pathways, and the potential for targeting these pathways in the prevention and treatment of breast cancer is well recognized, although not yet realized.

To date, most investigations into the role of FAM in breast cancer have failed to take into account the heterogeneous nature of the disease. There has been little effort to define alterations in FAM pathways with respect to intrinsic molecular subtype. Generalizations concerning fatty acid metabolism in breast cancer, therefore, are likely derived from, and characteristic of, the most prevalent forms of the disease, i.e., estrogen receptor alpha (ER) positive subtypes.

In the following essay we review data relevant to the role of altered FAM in sustaining the proliferation and progression of breast cancer, with emphasis on pathways that appear specific for individual molecular subtypes. Published data is accompanied by a meta-analysis of public gene expression data that suggest that future approaches to exploit FAM pathways in the prevention and treatment of breast cancer should be tailored to individual molecular subtypes.

\section{PATTERNS OF EXPRESSION FOR FAM GENES DIFFER BY MOLECULAR SUBTYPE}

Within the last 15 years, a number of studies have utilized mRNA expression patterns to subtype breast cancers according to molecular signatures that might predict clinical outcomes [1]. Although these subtypes are generally comparable to receptor status as determined by immunostaining (ER, progesterone receptor (PR) and human epidermal growth factor receptor 2 (HER2)), there are, nevertheless, refinements that have proved useful. In the case of the PAM50 molecular signature [2], which utilizes a 50-gene mRNA expression panel, tumors are 
classified as luminal A (ER+, $\mathrm{PR}+)$, luminal $\mathrm{B}(\mathrm{ER}+$, PR+ or PR-), HER2-enriched (HER2+), basal-like (ER-, PR-, androgen receptor negative (AR-)) and normal-like [3]. Whether the normal-like category is a distinct breast cancer subtype or reflects contamination with normal cells is not yet clear [4]. The luminal A, receptor positive, subtype has the best prognosis. Triple negative breast cancers (TNBC), designated as such by immunostaining, fall predominantly (79\%) into the basal-like category, with $8 \%$ HER2-enriched, 7\% luminal A and luminal B and 7\% normal-like [4]. It has already been determined that AR+ TNBC are markedly different and should be considered as a separate category [4-6]. AR+ TNBC can fall into either the luminal or HER2-enriched category. It has been suggested that AR- TNBC be referred to as quadruple negative breast cancer (QNBC) $[7,8]$.

Figure 1 depicts pathways of FAM, including the relationship of FAM to glucose and glutamine metabolism, highlighting aspects found to be relevant to sustaining growth and survival of breast cancer cells. In a survey of gene expression data on the Oncomine site [9], relative mRNA expression levels for entities that are preferentially expressed in TNBC versus receptor-positive breast cancers (RPBC) are depicted in red, while those preferentially expressed in RPBC are in blue. Table 1a is an overview of the results from 21 different studies comparing expression in TNBC with that in RPBC. Table $1 \mathrm{~b}$ details the differences as demonstrated in results from 6 of those studies: 5 involving tissue samples [10-14] and one utilizing breast cancer cell lines [15]. While these data are not necessarily reflective of protein expression or activity levels, they nevertheless suggest a clear-cut trend indicating that TNBC, in addition to relying more heavily on uptake of glucose (SLC2A1) and glutamine (SLC6A14), also appear to be more dependent on uptake and storage of exogenous fatty acids than RPBC, which instead up regulates de novo fatty acid synthesis, mobilization and oxidation to a greater degree than TNBC. This conclusion has been confirmed in a recent report of a lipid metabolism gene signature comparing TNBC to RNBC [16]. A comparison of the cell line data from Table $1 \mathrm{~b}$ with the tissue data indicates that the preferential expression of many of the FAM genes observed in vivo is recapitulated in in vitro models. Note that these data do not address the question of expression relative to normal breast. Normal luminal epithelial cells differ from luminal breast cancers in that only a minority of the normal cells are $\mathrm{ER}+(15-30 \%)[17]$, and cell lines derived from

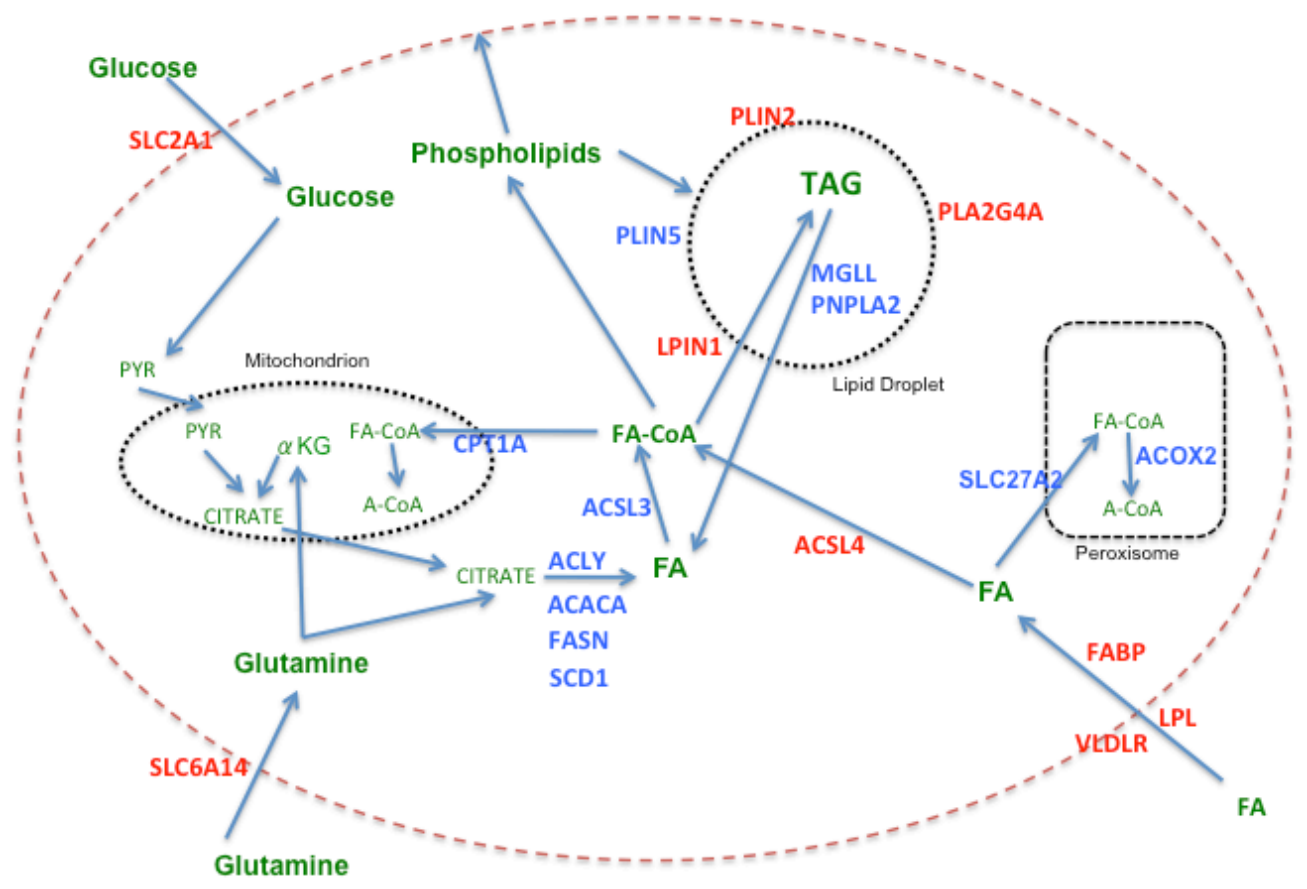

Figure 1: Fatty acid metabolism in breast cancer. Color code: Red = genes more highly expressed in TNBC versus RPBC; Blue = genes more highly expressed in RPBC versus TNBC; Green = metabolic substrates. Abbreviations: ACACA: acetyl-CoA carboxylase alpha; ACLY: ATP citrate lyase; ACOX2: acyl-CoA oxidase 2, branched chain; ACSL: long chain fatty acyl-CoA synthetase; CPT1A: carnitine palmitoyltransferase 1A; FABP: fatty acid binding protein; FASN: fatty acid synthase; LPIN1: lipin 1 (also known as phosphatidic acid phosphohydralase (PAP); LPL: lipoprotein lipase; MGLL: monoglyceride lipase; PLA2G4A: phospholipase A2, group IVA (also known as cytosolic phospholipase A2 (cPLA2);PLIN: perilipin; PNPLA2: palatin-like phospholipase domain containing 2 (also known as ATGL, adipocyte triglycderide lipase); SCD1: stearoyl-CoA desaturase 1; SLC2A1: Solute carrier family 2 member 1 (also know as GLUT1, glucose transporter 1); SLC6A14: solute carrier family 6 (amino acid transporter) member 14; SLC27A2: solute carrier family 27 member 2 (also known as ACSVL1, very long chain fatty acyl-CoA synthetase 1), FA: fatty acid; PYR: pyruvate; $\alpha$ KG: alpha ketoglutarate; A-CoA: acetylCoA; FA-CoA: fatty acyl-CoA. 
Table 1A: Overview of fatty acid metabolism gene mRNA expression in breast cancer

\begin{tabular}{|c|c|c|c|c|c|c|}
\hline & & \multicolumn{5}{|c|}{ TNBC relative to $R P B C$} \\
\hline & & \multicolumn{2}{|c|}{ CHANGE $(\mathrm{P}<0.05)$} & \multicolumn{2}{|c|}{ CHANGE (NS) } & \multirow[t]{2}{*}{ NO. of STUDIES } \\
\hline & & $\uparrow$ & $\downarrow$ & $\uparrow$ & $\downarrow$ & \\
\hline & GENE & & & & & \\
\hline \multicolumn{7}{|l|}{ FUNCTION } \\
\hline \multirow[t]{5}{*}{ Synthesis } & ACLY & 0 & 9 & 3 & 9 & 21 \\
\hline & ACACA & 0 & 13 & 2 & 6 & 21 \\
\hline & FASN & 0 & 14 & 3 & 4 & 21 \\
\hline & SCD1 & 0 & 12 & 0 & 9 & 21 \\
\hline & SREBP1 & 0 & 19 & 0 & 2 & 21 \\
\hline \multirow[t]{4}{*}{ Transport } & VLDLR & 15 & 0 & 4 & 1 & 20 \\
\hline & LPL & 10 & 0 & 8 & 3 & 21 \\
\hline & FABP5 & 18 & 0 & 2 & 1 & 21 \\
\hline & FABP7 & 15 & 0 & 5 & 1 & 21 \\
\hline \multirow[t]{3}{*}{ Activation } & ACSL3 & 1 & 14 & 1 & 4 & 20 \\
\hline & ACSL4 & 15 & 0 & 5 & 1 & 21 \\
\hline & SLC27A2 & 0 & 17 & 1 & 2 & 21 \\
\hline \multirow[t]{3}{*}{ Storage } & PLIN2 & 18 & 0 & 2 & 1 & 21 \\
\hline & PLIN5 & 0 & 8 & 0 & 5 & 13 \\
\hline & LPIN1 & 19 & 0 & 1 & 1 & 21 \\
\hline \multirow[t]{3}{*}{ Mobilization } & MMGL & 0 & 14 & 2 & 5 & 21 \\
\hline & PNPLA2 & 1 & 11 & 3 & 6 & 21 \\
\hline & PLA2G4A & 16 & 0 & 4 & 1 & 21 \\
\hline \multirow[t]{2}{*}{ Oxidation } & CPT1A & 1 & 16 & 1 & 3 & 21 \\
\hline & $\mathrm{ACOX} 2$ & 0 & 20 & 1 & 0 & 21 \\
\hline \multicolumn{7}{|l|}{ Uptake of } \\
\hline Glucose & SLC2A1 & 11 & 1 & 8 & 1 & 21 \\
\hline Glutamine & SLC6A14 & 15 & 0 & 1 & 2 & 18 \\
\hline
\end{tabular}

Data taken from Oncomine [9].

normal breast are most closely aligned with the basal-like, receptor-negative subtype [18].

As detailed above, the TNBC designation, although similar to, is not synonymous with classification of breast tumors according to gene signatures, such as PAM50 [19]. To determine whether the pattern suggested by the data shown in Table 1 persisted when samples were grouped by PAM50 subtype rather than receptor status, the expression of the same genes was evaluated as a function of subtype in 3 separate studies detailed in the Oncomine database $[11,12,20]$. Table 2 details the results, which reflect the relative degree of expression of a particular mRNA in a given subtype. The results generally mirror those obtained when expression is classified as a function of receptor status (Table 1). Note that each study utilizes a different microarray platform, which might explain minor differences between studies. Thus, whether utilizing receptor status or PAM50 classification, clear differences are observed with respect to relative mRNA expression levels for FAM proteins, with de novo fatty acid synthesis and oxidation predominating in RPBC, while uptake and storage of exogenous fatty acids predominate in QNBC.

Lastly, to further assess the importance of individual FAM proteins in mediating an aggressive breast cancer phenotype, we utilized public mRNA expression data [21] to determine the effect of silencing ER on expression of mRNA for FAM proteins in MCF7 cells. Results are shown in Table 3. Expression levels of mRNA for a number of proteins more highly expressed in TNBC were increased following silencing of ER, including VLDLR, FABP5, ACSL4, PLIN2, and PLA2G4A, while expression of some of those more highly expressed in RPBC was significantly decreased, including ACACA, FASN, SCD1, ACSL3, SLC27A2, PLIN5, MGLL and CPT1A. Of the 17 proteins that are expressed in MCF7 cells, 13 responded to ablation of ER activity with the expected change predicted by expression patterns summarized in Table 1. Considering that there are most likely major differences between the environment of tumor cells in vivo and in vitro, as well as the probability that there are also significant differences 
Table 1B: Fatty acid metabolism in TNBC compared with RPBC

\begin{tabular}{|c|c|c|c|c|c|c|c|c|c|c|c|c|c|}
\hline & & \multicolumn{12}{|c|}{ STUDY } \\
\hline & & \multicolumn{2}{|c|}{$\begin{array}{c}\text { Chin } \\
(n=19,87)\end{array}$} & \multicolumn{2}{|c|}{$\begin{array}{c}\text { Curtis } \\
(n=211,1340)\end{array}$} & \multicolumn{2}{|c|}{$\begin{array}{c}\text { Hatzis } \\
(n=178,320)\end{array}$} & \multicolumn{2}{|c|}{$\begin{array}{c}\text { Richardson2 } \\
(n=18,19)\end{array}$} & \multicolumn{2}{|c|}{$\begin{array}{c}\text { TCGA } \\
(n=46,250)\end{array}$} & \multicolumn{2}{|c|}{$\begin{array}{c}\text { Neve } \\
(n=21,25)\end{array}$} \\
\hline & & FC & $\mathrm{pV}$ & FC & $\mathrm{pV}$ & FC & $\mathbf{p V}$ & FC & $\mathrm{pV}$ & FC & $\mathrm{pV}$ & FC & $\mathrm{pV}$ \\
\hline & GENE & & & & & & & & & & & & \\
\hline \multicolumn{14}{|l|}{ FUNCTION } \\
\hline \multirow[t]{5}{*}{ Synthesis } & ACLY & -1.25 & 0.013 & -1.22 & $2.56 \mathrm{e}-14$ & -1.08 & 0.008 & -1.53 & 0.007 & -1.13 & 0.019 & -1.16 & 0.092 \\
\hline & ACACA & -1.22 & $1.30 \mathrm{e}-05$ & -1.21 & $1.81 \mathrm{e}-09$ & -1.08 & $1.12 \mathrm{e}-04$ & -1.49 & 0.038 & -1.25 & 0.003 & -1.14 & 0.014 \\
\hline & \begin{tabular}{|l|} 
FASN \\
\end{tabular} & -1.86 & \begin{tabular}{|l|}
0.003 \\
\end{tabular} & -1.60 & $7.83 \mathrm{e}-16$ & -1.72 & $2.33 \mathrm{e}-15$ & -6.37 & $3.12 \mathrm{e}-08$ & -2.22 & $1.20 \mathrm{e}-14$ & -2.11 & $1.36 \mathrm{e}-04$ \\
\hline & \begin{tabular}{|l|} 
SCD1 \\
\end{tabular} & -1.65 & 0.006 & -1.27 & $1.15 \mathrm{e}-06$ & -1.52 & $6.25 \mathrm{e}-08$ & -2.17 & \begin{tabular}{|l|}
0.004 \\
\end{tabular} & -2.23 & \begin{tabular}{|l|}
$1.07 \mathrm{e}-07$ \\
\end{tabular} & -1.82 & 0.002 \\
\hline & SREBP1 & -1.81 & $3.91 \mathrm{e}-05$ & -1.85 & $5.46 \mathrm{e}-38$ & -1.66 & $1.37 \mathrm{e}-26$ & -2.76 & $2.82 \mathrm{e}-04$ & -2.18 & $1.14 \mathrm{e}-14$ & -1.49 & 0.001 \\
\hline \multirow[t]{4}{*}{ Transport } & \begin{tabular}{|l} 
VLDLR \\
\end{tabular} & 1.54 & 0.007 & 1.67 & $1.14 \mathrm{e}-29$ & 1.44 & $2.12 \mathrm{e}-17$ & 2.33 & 0.022 & 2.26 & $8.47 \mathrm{e}-10$ & 1.35 & 0.043 \\
\hline & LPL & 1.45 & 0.049 & 1.28 & $9.54 \mathrm{e}-07$ & 1.31 & $1.85 \mathrm{e}-04$ & 3.74 & 0.001 & 1.47 & 0.028 & 1.18 & 0.079 \\
\hline & FABP5 & 2.29 & $3.05 \mathrm{e}-06$ & 2.47 & $5.66 \mathrm{e}-44$ & 2.60 & $1.15 \mathrm{e}-23$ & 4.38 & $1.48 \mathrm{e}-05$ & 3.58 & $3.59 \mathrm{e}-21$ & 5.41 & 0.007 \\
\hline & FABP7 & 8.27 & $2.86 \mathrm{e}-04$ & 2.80 & 0.013 & 2.37 & $7.49 \mathrm{e}-14$ & 78.03 & $1.41 \mathrm{e}-07$ & 23.50 & $6.59 \mathrm{e}-16$ & -1.39 & 0.08 \\
\hline \multirow[t]{3}{*}{ Activation } & ACSL3 & -1.69 & $6.22 \mathrm{e}-04$ & -1.16 & $2.21 \mathrm{e}-07$ & -1.38 & $1.25 \mathrm{e}-07$ & -1.43 & 0.044 & -1.39 & $6.75 \mathrm{e}-04$ & -1.69 & 0.007 \\
\hline & ACSL4 & 1.40 & $8.46 \mathrm{e}-04$ & 1.43 & $1.13 \mathrm{e}-28$ & 1.13 & $5.93 \mathrm{e}-10$ & 1.84 & 0.002 & 1.64 & \begin{tabular}{|l}
$8.40 \mathrm{e}-09$ \\
\end{tabular} & 1.92 & $1.90 \mathrm{e}-05$ \\
\hline & SLC27A2 & -2.10 & $5.72 \mathrm{e}-09$ & -2.04 & $8.15 \mathrm{e}-80$ & -1.54 & $4.03 \mathrm{e}-18$ & -1.64 & 0.008 & .4 .00 & $9.70 \mathrm{e}-27$ & -1.32 & 0.045 \\
\hline \multirow[t]{3}{*}{ Storage } & PLIN2 & 1.68 & $2.22 \mathrm{e}-05$ & 1.94 & $6.02 \mathrm{e}-36$ & 1.88 & $6.81 \mathrm{e}-21$ & 1.70 & 0.016 & 2.17 & $8.13 \mathrm{e}-14$ & 1.62 & 0.023 \\
\hline & PLIN5 & NA & $\begin{array}{ll}\mathrm{NA} \\
\end{array}$ & -1.10 & $4.15 \mathrm{e}-27$ & NA & NA & -1.24 & 0.007 & -3.20 & $6.89 \mathrm{e}-10$ & NA & NA \\
\hline & LPIN1 & 2.43 & $4.76 \mathrm{e}-08$ & 2.19 & $8.21 \mathrm{e}-55$ & 1.85 & $6.62 \mathrm{e}-27$ & 3.16 & $2.64 \mathrm{e}-06$ & 2.98 & $1.40 \mathrm{e}-15$ & 1.34 & 0.014 \\
\hline \multirow[t]{3}{*}{ Mobilization } & MGLL & -1.81 & $1.64 \mathrm{e}-04$ & -1.25 & 4.11e-10 & -1.24 & $1.26 \mathrm{e}-06$ & -2.43 & \begin{tabular}{|l|}
0.003 \\
\end{tabular} & -1.64 & $2.75 \mathrm{e}-05$ & -1.39 & \begin{tabular}{|l|}
0.051 \\
\end{tabular} \\
\hline & PNPLA2 & -1.06 & 0.219 & \begin{tabular}{|l|}
-1.32 \\
\end{tabular} & $8.56 \mathrm{e}-25$ & -1.05 & 0.002 & -1.18 & 0.046 & -1.30 & $9.83 \mathrm{e}-06$ & -1.10 & 0.011 \\
\hline & PLA2G4A & 3.13 & $9.26 \mathrm{e}-05$ & 1.06 & 6.31e-09 & 1.33 & $4.11 \mathrm{e}-09$ & 6.47 & $1.69 \mathrm{e}-04$ & 3.91 & $3.07 \mathrm{e}-12$ & 1.38 & 0.055 \\
\hline \multirow[t]{2}{*}{ Oxidation } & CPT1A & -1.65 & $4.08 \mathrm{e}-05$ & -1.07 & $4.78 \mathrm{e}-12$ & -1.20 & $5.80 \mathrm{e}-09$ & -2.21 & 0.001 & -1.72 & $4.05 \mathrm{e}-10$ & -2.46 & $6.51 \mathrm{e}-07$ \\
\hline & ACOX2 & -4.11 & $1.36 \mathrm{e}-18$ & -3.97 & $8.20 \mathrm{e}-74$ & -1.62 & $1.74 \mathrm{e}-23$ & -7.37 & $1.89 \mathrm{e}-04$ & -5.87 & $5.82 \mathrm{e}-23$ & -1.61 & 0.009 \\
\hline \multicolumn{14}{|l|}{ Uptake of } \\
\hline Glucose & SLC2A1 & 1.56 & 0.004 & 1.79 & $2.80 \mathrm{e}-26$ & 1.14 & $5.40 \mathrm{e}-07$ & 1.86 & 0.003 & 1.74 & $4.73 \mathrm{e}-07$ & 1.07 & 0.908 \\
\hline Glutamine & SLC6A14 & 2.44 & 0.003 & 1.29 & $1.12 \mathrm{e}-16$ & 1.84 & $2.00 \mathrm{e}-14$ & 9.78 & $2.78 \mathrm{e}-04$ & 15.74 & $2.69 \mathrm{e}-17$ & 1.01 & 0.476 \\
\hline
\end{tabular}

Data taken from 6 separate studies as reported on Oncomine [9]. The numbers in parentheses indicate sample size ( $\mathrm{n}=\mathrm{TNBC}$, RPBC)

Abbreviations: $\mathrm{FC}=$ fold change ( $\log 2$ median-centered intensity)

$\mathrm{pV}=\mathrm{p}$ value

$\mathrm{NA}=$ not available

between naturally arising TNBC and forced ablation of ER only, the degree of symmetry is strong evidence of the validity of the analysis. These data further support the idea that expression patterns of FAM proteins are aligned with intrinsic molecular subtypes in breast cancer.

Published data relative to the role of individual FAM proteins in breast cancer is summarized below.

\section{DE NOVO FATTY ACID SYNTHESIS}

In most human tissues, the de novo pathway of fatty acid synthesis is of minor importance, the exceptions being liver and mammary gland, and, to a lesser extent, adipose tissue [22]. The cellular requirement for fatty acids is generally met by utilization of dietary fatty acids. The differential importance of this pathway with respect to normal versus cancer tissue makes it an attractive target for therapy.

\section{ATP citrate lyase (ACLY)}

As noted in Figure 1, the acetyl CoA required for fatty acid synthesis is derived from citrate via catalysis by the enzyme ACLY. Increased ACLY expression and activity have been noted in a number of cancers, including breast, leading to the suggestion that it is a key player in cancer metabolism [23]. This enzyme appears to be elevated in breast malignancies [24], and its inhibition by RNAi or the chemical inhibitor SB-204990 has a negative effect on proliferation and growth both in vitro and in vivo [25]. Steeg et. al. have suggested that phosphorylation of ACLY by the Nm23-H1 metastasis suppressor may play a role in limiting migration and invasion of tumor cells [26]. It has recently been reported that ACLY is required for cyclin E-mediated transformation, migration and invasion of breast cancer cells in vitro, as well as for tumor growth in vivo [27]. ACLY mRNA is most highly expressed in the HER2-enriched subtype, and therefore underexpressed in TNBC relative to RPBC. 
Table 2: Expression of fatty acid metabolism genes as a function of intrinsic molecular subtype (PAM50)

\begin{tabular}{|c|c|c|c|c|c|c|c|c|c|c|c|c|c|c|c|c|}
\hline & & \multicolumn{15}{|c|}{ STUDY } \\
\hline & & \multicolumn{5}{|c|}{$\begin{array}{c}\text { Curtis } \\
(n=1986) \\
\text { Illumina }\end{array}$} & \multicolumn{5}{|c|}{$\begin{array}{c}\text { Esserman } \\
(n=129) \\
\text { Agilent }\end{array}$} & \multicolumn{5}{|c|}{$\begin{array}{c}\text { Hatzis } \\
(n=508) \\
\text { Affymetrix }\end{array}$} \\
\hline & & \multicolumn{5}{|c|}{ Rank } & \multicolumn{5}{|c|}{ Rank } & \multicolumn{5}{|c|}{ Rank } \\
\hline FUNCTION & GENE & 1 & 2 & 3 & 4 & 5 & 1 & 2 & 3 & 4 & 5 & 1 & 2 & 3 & 4 & 5 \\
\hline \multirow[t]{5}{*}{ Synthesis } & ACLY & $\mathrm{L}$ & $\mathrm{H}$ & A & B & $\mathrm{N}$ & $\mathrm{H}$ & A & $\mathrm{L}$ & B & $\mathrm{N}$ & $\mathrm{H}$ & $\mathrm{L}$ & $\mathrm{A}$ & B & $\mathrm{N}$ \\
\hline & ACACA & $\mathrm{N}$ & B & A & $\mathrm{L}$ & $\mathrm{H}$ & $\mathrm{L}$ & A & $\mathrm{H}$ & B & $\mathrm{N}$ & $\mathrm{H}$ & $\mathrm{L}$ & A & $\mathrm{N}$ & $\mathrm{B}$ \\
\hline & FASN & $\mathrm{H}$ & A & $\mathrm{L}$ & $\mathrm{N}$ & B & $\mathrm{L}$ & $\mathrm{H}$ & A & $\mathrm{B}$ & $\mathrm{N}$ & $\mathrm{L}$ & A & $\mathrm{H}$ & $\mathrm{N}$ & $\mathrm{B}$ \\
\hline & SCD1 & $\mathrm{H}$ & $\mathrm{L}$ & A & $\mathrm{N}$ & B & $\mathrm{H}$ & $\mathrm{N}$ & B & A & $\mathrm{L}$ & $\mathrm{H}$ & $\mathrm{L}$ & $\mathrm{N}$ & A & $\mathrm{B}$ \\
\hline & SREBP1 & A & $\mathrm{L}$ & $\mathrm{H}$ & $\mathrm{N}$ & B & $\mathrm{L}$ & $\mathrm{N}$ & A & $\mathrm{H}$ & B & A & $\mathrm{L}$ & $\mathrm{H}$ & $\mathrm{N}$ & $\mathrm{B}$ \\
\hline \multirow[t]{4}{*}{ Transport } & VLDLR & B & $\mathrm{H}$ & A & $\mathrm{L}$ & $\mathrm{N}$ & B & $\mathrm{N}$ & $\mathrm{H}$ & A & $\mathrm{L}$ & B & $\mathrm{H}$ & $\mathrm{N}$ & A & $\mathrm{L}$ \\
\hline & LPL & $\mathrm{N}$ & B & A & $\mathrm{L}$ & $\mathrm{H}$ & $\mathrm{N}$ & $\mathrm{B}$ & $\mathrm{H}$ & A & $\mathrm{L}$ & $\mathrm{N}$ & B & A & $\mathrm{H}$ & $\mathrm{L}$ \\
\hline & FABP5 & B & $\mathrm{N}$ & $\mathrm{L}$ & $\mathrm{H}$ & A & B & $\mathrm{H}$ & $\mathrm{N}$ & $\mathrm{L}$ & A & B & $\mathrm{N}$ & $\mathrm{H}$ & $\mathrm{L}$ & $\mathrm{A}$ \\
\hline & FABP7 & $\mathrm{B}$ & $\mathrm{N}$ & $\mathrm{H}$ & A & $\mathrm{L}$ & $\mathrm{N}$ & $\mathrm{B}$ & $\mathrm{H}$ & A & $\mathrm{L}$ & $\mathrm{B}$ & $\mathrm{N}$ & $\mathrm{H}$ & A & $\mathrm{L}$ \\
\hline \multirow[t]{3}{*}{ Activation } & ACSL3 & $\mathrm{H}$ & $\mathrm{N}$ & $\mathrm{L}$ & $\mathrm{A}$ & B & $\mathrm{L}$ & A & $\mathrm{N}$ & B & $\mathrm{H}$ & $\mathrm{L}$ & $\mathrm{H}$ & A & $\mathrm{N}$ & B \\
\hline & ACSL4 & B & $\mathrm{N}$ & $\mathrm{H}$ & $\mathrm{A}$ & $\mathrm{L}$ & B & $\mathrm{H}$ & $\mathrm{L}$ & $\mathrm{N}$ & A & B & $\mathrm{N}$ & $\mathrm{H}$ & $\mathrm{L}$ & $\mathrm{A}$ \\
\hline & SLC27A2 & $\mathrm{L}$ & A & $\mathrm{N}$ & $\mathrm{H}$ & B & $\mathrm{A}$ & $\mathrm{L}$ & $\mathrm{N}$ & $\mathrm{H}$ & B & A & $\mathrm{L}$ & $\mathrm{H}$ & $\mathrm{N}$ & B \\
\hline \multirow[t]{3}{*}{ Storage } & PLIN2 & B & $\mathrm{N}$ & $\mathrm{H}$ & $\mathrm{L}$ & A & B & $\mathrm{H}$ & $\mathrm{L}$ & $\mathrm{N}$ & A & B & $\mathrm{H}$ & $\mathrm{N}$ & $\mathrm{L}$ & A \\
\hline & PLIN5 & A & $\mathrm{L}$ & $\mathrm{N}$ & $\mathrm{H}$ & B & $\mathrm{L}$ & A & $\mathrm{N}$ & B & $\mathrm{H}$ & na & na & na & na & na \\
\hline & LPIN1 & $\mathrm{B}$ & $\mathrm{N}$ & $\mathrm{H}$ & $\mathrm{A}$ & $\mathrm{L}$ & $\mathrm{N}$ & $\mathrm{B}$ & $\mathrm{H}$ & $\mathrm{L}$ & A & B & $\mathrm{N}$ & $\mathrm{H}$ & $\mathrm{L}$ & A \\
\hline \multirow[t]{3}{*}{ Mobilization } & MGLL & $\mathrm{N}$ & $\mathrm{H}$ & A & $\mathrm{L}$ & B & $\mathrm{N}$ & A & $\mathrm{H}$ & $\mathrm{L}$ & B & $\mathrm{N}$ & $\mathrm{H}$ & A & $\mathrm{L}$ & B \\
\hline & PNPLA2 & A & $\mathrm{N}$ & $\mathrm{L}$ & $\mathrm{H}$ & B & $\mathrm{A}$ & $\mathrm{H}$ & $\mathrm{L}$ & B & $\mathrm{N}$ & $\mathrm{N}$ & A & B & $\mathrm{L}$ & $\mathrm{H}$ \\
\hline & PLA2G4A & $\mathrm{B}$ & $\mathrm{N}$ & $\mathrm{A}$ & $\mathrm{L}$ & $\mathrm{H}$ & B & $\mathrm{H}$ & $\mathrm{N}$ & $\mathrm{A}$ & $\mathrm{L}$ & B & $\mathrm{N}$ & $\mathrm{H}$ & $\mathrm{A}$ & $\mathrm{L}$ \\
\hline \multirow[t]{2}{*}{ Oxidation } & CPT1A & $\mathrm{H}$ & B & $\mathrm{L}$ & $\mathrm{N}$ & $\mathrm{A}$ & $\mathrm{H}$ & $\mathrm{L}$ & $\mathrm{A}$ & $\mathrm{N}$ & B & $\mathrm{L}$ & $\mathrm{H}$ & A & $\mathrm{N}$ & $\mathrm{B}$ \\
\hline & $\mathrm{ACOX} 2$ & $\mathrm{~A}$ & $\mathrm{~L}$ & $\mathrm{H}$ & $\mathrm{N}$ & B & A & $\mathrm{N}$ & $\mathrm{L}$ & $\mathrm{H}$ & B & $\mathrm{L}$ & $\mathrm{A}$ & $\mathrm{N}$ & A & B \\
\hline \multicolumn{17}{|l|}{ Uptake of } \\
\hline glucose & SLC2A1 & $\mathrm{B}$ & $\mathrm{H}$ & $\mathrm{L}$ & A & $\mathrm{N}$ & B & $\mathrm{L}$ & $\mathrm{H}$ & A & $\mathrm{N}$ & B & $\mathrm{H}$ & $\mathrm{N}$ & A & $\mathrm{L}$ \\
\hline glutamine & SLC6A14 & B & $\mathrm{N}$ & $\mathrm{H}$ & A & $\mathrm{L}$ & B & $\mathrm{H}$ & $\mathrm{L}$ & $\mathrm{N}$ & A & B & $\mathrm{N}$ & $\mathrm{H}$ & A & $\mathrm{L}$ \\
\hline
\end{tabular}

Data taken from Oncomine [9]. Subtypes with highest and lowest expression indicated as rank 1 to 5, respectively. Abbreviations: $\mathrm{n}=$ sample number; $\mathrm{A}=$ luminal $\mathrm{A} ; \mathrm{L}=$ luminal $\mathrm{B} ; \mathrm{H}=\mathrm{HER} 2$-enriched; $\mathrm{B}=$ basal-like; $\mathrm{N}=$ normal-like. The designation under the sample number refers to the microarray platform

\section{Acetyl CoA carboxylase alpha (ACACA)}

The rate-limiting step in the synthesis of fatty acids is the ATP-dependent conversion of acetyl CoA to malonyl CoA by the enzyme, acetyl CoA carboxylase (ACAC). Two isoforms have been identified, ACACA (also called ACC1) and ACACB (also called ACC2). A number of studies have implicated ACACA activity in the malignant phenotype of breast cancer. An early immunohistochemical study of human breast tissue samples noted that expression of both ACAC isoforms was elevated upon development of either in situ duct or lobular carcinoma [28]. More recently, it has been demonstrated that silencing of the ACACA gene in human breast cancer cells in long-term culture as a result of RNA interference results in decreased palmitic acid synthesis and the induction of apoptosis [29]. Data also suggest that HER2 overexpression plays a role in increasing ACACA activity [30]. Breast cancer cell lines that overexpress
HER2 (SK-BR-3 and BT-474) express higher levels of ACACA than those in which expression of HER2 is relatively low (MCF-7 and MDA-MB-231). Exogenous expression of HER2 in MDA-MB-231 cells induced expression of ACACA that appeared to be mediated at the translational level by mTOR via the PI3K/Akt pathway. And when MCF7 cells were engineered to overexpress HER2 they became 5 times more sensitive to ACACA inhibition-induced reductions in mammosphere-forming efficiency [31]. The mRNA data for ACACA indicate that expression is decreased in TNBC relative to RNBC (Table $1 \mathrm{~A}$ and $1 \mathrm{~B}$ ) in both tissue samples and cell lines, and that silencing of ER in MCF7 cells decreases expression by 4-fold (Table 3).

\section{Fatty acid synthase (FASN)}

The most extensively studied of the lipogenic enzymes in the context of carcinogenesis is FASN (for 
Table 3: Effect of ER $\alpha$ silencing on expression of fatty acid metabolic genes

\begin{tabular}{|l|c|c|c|c|c|}
\hline & & Control & Silenced & Fold Change & pValue \\
\hline Function & Gene & & & & \\
\hline Synthesis & ACLY & $1201 \pm 117$ & $1896 \pm 146$ & 1.57 & 0.003 \\
\hline & ACACA & $387 \pm 17$ & $95 \pm 2$ & -4.07 & $9.08 \mathrm{e}-06$ \\
\hline & FASN & $2863 \pm 353$ & $942 \pm 327$ & -3.03 & 0.002 \\
\hline & SCD1 & $7181 \pm 86$ & $3606 \pm 281$ & -1.99 & $3.02 \mathrm{e}-05$ \\
\hline & SREBP1 & $941 \pm 65$ & $383 \pm 34$ & -2.45 & $1.90 \mathrm{e}-04$ \\
\hline & VLDLR & $248 \pm 3$ & $383 \pm 45$ & 1.54 & 0.007 \\
\hline & LPL & $\mathrm{NE}$ & $\mathrm{NE}$ & & \\
\hline & FABP5 & $1566 \pm 54$ & $4101 \pm 269$ & 2.61 & $8.94 \mathrm{e}-05$ \\
\hline & FABP7 & $\mathrm{NE}$ & $\mathrm{NE}$ & & \\
\hline & ACSL3 & $2043 \pm 41$ & $1684 \pm 96$ & -1.21 & 0.004 \\
\hline & ACSL4 & $150 \pm 5$ & $1867 \pm 43$ & 12.44 & $2.30 \mathrm{e}-06$ \\
\hline & SLC27A2 & $913 \pm 60$ & $18 \pm 1$ & -50.72 & $1.39 \mathrm{e}-05$ \\
\hline Storage & PLIN2 & $95 \pm 9$ & $575 \pm 86$ & 6.05 & $6.70 \mathrm{e}-04$ \\
\hline & PLIN5 & $136 \pm 7$ & $46 \pm 5$ & -2.95 & $8.38 \mathrm{e}-05$ \\
\hline & LPIN1 & $86 \pm 6$ & $69 \pm 22$ & -1.24 & 0.266 \\
\hline Mobilization & MGLL & $948 \pm 17$ & $344 \pm 15$ & -2.76 & $1.39 \mathrm{e}-06$ \\
\hline & PNPLA2 & $170 \div 18$ & $186 \pm 34$ & 1.09 & 0.534 \\
\hline & PLA2G4A & $10 \pm 1$ & $127 \pm 7$ & 12.70 & $1.14 \mathrm{e}-05$ \\
\hline Oxidation & CPT1A & $141 \pm 7$ & $23 \pm 2$ & -6.13 & $1.06 \mathrm{e}-05$ \\
\hline & ACOX2 & $96 \pm 7$ & $759 \pm 61$ & 7.90 & $5.03 \mathrm{e}-05$ \\
\hline Uptake of & & & & & \\
\hline Glucose & SLC2A1 & $629 \pm 37$ & $3090 \pm 89$ & 4.91 & $1.61 \mathrm{e}-06$ \\
\hline Glutamine & SLC6A14 & $301 \pm 10$ & $23 \pm 2$ & -13.08 & $1.33 \mathrm{e}-06$ \\
\hline
\end{tabular}

Data shown are mRNA expression values in arbitrary units.

Abbreviations: $\mathrm{NE}=$ not expressed

Fold Change $=$ Silenced $/$ Control for positive changes; $=-1 \times$ Control/Silenced for negative changes

reviews, see [32-36]). Overexpression of this enzyme has been reported for a variety of cancers, including prostate, liver, ovary, colon, endometrium and breast, and has been associated with malignant transformation and a worse prognosis. Using the h-ras-induced transformation of the human mammary epithelial cell line, MCF10A, as a model, Yang et. al. demonstrated that upregulation of FASN activity was driven by increases in EGF signaling via a pathway including MAPK, PI3K and sterol regulatory element binding protein 1 (SREBP1). Inhibitors of the kinases lowered SREBP1 levels and decreased FASN transcription. Deletion of the SREBP binding site from the FAS promoter also decreased FAS transcription in the transformed cells [37]. HER2 is another member of the erbB2 family of receptor tyrosine kinases that has been demonstrated to play a role in regulation of FASN activity [38]. A transcriptome analysis comparing HER2-positive with HER2-negative breast cancer cell lines demonstrated that expression of FASN was increased in cells that were HER2-positive. Inhibition of HER2 activity with either Herceptin or a kinase inhibitor resulted in a reduction of FASN expression. HER2 was shown to stimulate the FAS promoter via a mechanism involving PI3K that ultimately resulted in increase incorporation of radiolabeled acetate into fatty acids [38]. More recently HER2 has also been shown to directly phosphorylate FASN, which results in activation of FASN activity [39]. Inhibition of FASN phosphorylation decreased invasion by SK-BR-3 and BT474 breast cancer cells. FASN has also been suggested to play the role of an oncogene in cell transformation. Forced overexpression of FASN in HBL100 and MCF$10 \mathrm{~A}$ cells caused these near normal breast cells to exhibit transformed properties and to increase expression levels of EGFR and HER2 [40]. When FASN mRNA expression is correlated with molecular subtype, there is a clear association between FASN and RPBC, such as HER2enriched, luminal A and luminal B, as shown in the 3 studies analyzed in Table 2. Immunochemical analysis of tumor samples confirms that FASN protein expression is highest in HER2 enriched tumors, and lowest in TNBC [41]. Like FASN, SREBP1 is preferentially expressed in RPBC (Tables 1 and 2).

\section{Stearoyl-CoA desaturase 1 (SCD1)}

The product of FASN activity is the long chain saturated fatty acids (SFA); however, in many instances 
the cell converts these SFAs to monounsaturated fatty acids before subsequent utilization [42]. The enzyme responsible for catalyzing the introduction of a double bond in the cis-delta-9 position is a fatty acyl-CoA delta 9 desaturase, also known as stearoyl-CoA desaturase (SCD). Two isoforms of SCD have been reported in human cells, SCD1 and SCD5 $[43,44]$. It has been suggested that SCD1 may play a key role in the generation of the malignant phenotype, as well as in the subsequent proliferation and survival of the cancer cell [45]. Recent data support a role for SCD1 activity in p53-induced attenuation of AKT signaling via modulation of the fatty acid composition of phosphoinositides [46]. Expression of SCD1 is ubiquitous in human tissues, while that of SCD5 is limited. SCD1 was reported to be overexpressed in transcriptome analyses of both HER2-overexpressing breast cancer cells [47] as well as in mucin-1 overexpressing breast cancer cells [48]. Estradiol induces SCD1 expression in ER+ breast cancer cells, MCF7 and T47D [49]. Pharmacologic inhibition of SCD activity reduced cell proliferation in human breast cancer cells MCF-7 and MDA-MB-231 [50]. Expression of SCD1 mRNA is highest in the HER2-enriched subtype in 3 different studies (Table 2).

\section{UPTAKE OF EXOGENOUS FATTY ACIDS}

In addition to de novo fatty acid synthesis, cancer cells can acquire needed fatty acids through uptake of dietary lipids or uptake of exogenous fatty acids released by cancer-associated adipocytes (CAA) [51]. A review of pathways exploited by the cancer cell to meet the need for fatty acids can be found in reference [52]. Two of the proteins involved in cellular acquisition of external lipids are lipoprotein lipase (LPL) and the very low density lipoprotein receptor (VLDLR). Intracellular transport of acquired lipids is accomplished by fatty acid binding proteins (FABPs).

\section{Lipoprotein lipase (LPL)}

Although it was originally thought that breast cancer cells did not have access to circulating lipids due to lack of LPL, a more recent study confirmed that basal-like breast cancer cell lines express significant levels of LPL mRNA [53]. In the same study, the majority of breast tumor tissues were positive for LPL when examined immunohistochemically. In our analysis of mRNA expression by tumor tissue shown in Tables 1 and 2, we found preferential expression of LPL mRNA in TNBC and normal-like and basal-like tissue samples.

\section{Very low density lipoprotein receptor (VLDLR)}

VLDLR is a plasma membrane lipoprotein receptor that mediates uptake of exogenous cholesterol and triglycerides. He et al found that VLDLR (variant II) protein expression was upregulated in breast tumor versus normal tissue and that expression levels were positively associated with lymph node and distant metastases [54]. In our analysis, VLDLR mRNA expression was elevated in TNBC and receptor-negative molecular subtypes (Tables 2 and 3). Silencing of ER in MCF7 cells increased VLDLR mRNA expression (Table 3 ).

\section{Fatty acid binding proteins (FABP5 \& FABP7)}

Fatty acid binding proteins are a family of cytoplasmic proteins that bind long chain fatty acids facilitating uptake into the cell and transport to subcellular organelles. Aberrant expression of FABPs has been associated with a number of disease states, including metabolic disease, non-alcoholic fatty liver disease, cardiovascular disease and cancer [55]. Overexpression of both FABP5 and FABP7 have been associated with TNBC and the basal-like subtype of breast cancer [5658]. Genetic ablation of FABP5 prevents mammary tumorigenesis in mice [59]. The accumulation of lipid droplets during hypoxia, which is required for survival after reoxygenation, is dependent on expression of FABP7 and FABP3, as well as PLIN2 [60]. Tables 1 and 2 indicate that both FABP5 and 7 mRNAs are overexpressed in TNBC.

\section{FATTY ACID ACTIVATION}

The metabolism of long-chain fatty acids in the synthesis of more complex lipids or as substrates for oxidation processes requires an activation step in the form of thioesterification. While the conversion of arachidonic acid to eicosanoids does not utilize the thioester intermediate directly, recent evidence in breast cancer cells and arterial smooth muscle cells [61, 62] suggests a pathway of arachidonic acid metabolism to prostaglandin E2 (PGE2) that is predicated on the prior storage and subsequent mobilization of arachidonate substrate, thus the conversion of arachidonic acid to arachidonoyl-CoA becomes associated with increased, rather than decreased prostaglandin production.

To date, 5 mammalian ACSL isoforms that differ in subcellular location and substrate specificity have been identified [63]. It has been suggested that ACSL enzymes function as cancer survival factors [64]. ACSL4 is the most extensively studied with respect to the malignant phenotype. ACSL4 has a marked preference for arachidonic acid as substrate and is located primarily in peroxisomes and on the mitochondria-associated membrane as a peripheral, rather than integral, membrane protein $[65,66]$. ACSL4 has more recently been localized to activated lipid droplets [67]. With respect to malignant transformation, ACSL4 is overexpressed in hepatocellular 
carcinoma $[68,69]$ as well as in colon adenocarcinoma [70], and has been demonstrated to play a role in the more aggressive forms of breast cancer [7, 61, 71-75]. As demonstrated in tables 1 and 2, ACSL4 mRNA is significantly overexpressed in TNBC and basal-like breast cancers, while ACSL3 mRNA expression predominates in RPBC and luminal and HER2-enriched subtypes. Silencing of ER in MCF7 cells results in a 12-fold increase in ACSL4 mRNA, while reducing that for ACSL3 1.21fold (Table 3 ).

The differential mRNA expression data for ACSL4 shown in Tables 1-3 have been validated with respect to protein expression $[61,71]$ as has the role of ACSL4 in mediating the expression of an aggressive phenotype in breast cancer cells $[7,61,76]$. The data further suggest that ACSL4 might function as a potential biomarker for QNBC as well as for hormone resistance when expressed in RPBC. Since forced expression of ACSL4 in breast cancer cells both increases COX-2 protein as well as production of PGE2 [61], it has been suggested that a combinatorial approach of targeting both ACSL4 and COX-2 might comprise an effective therapy for more aggressive breast cancers $[72,76]$. A role for the mTOR pathway as well as the lipoxygenase pathway has also been been indicated by recent data [73]. Forced expression of ACSL4 in MCF7 and $\mathrm{SKBr} 3$ cells reduces expression of AUTS 2 mRNA by $90 \%$, suggesting that this transcription factor may play a role in mammary differentiation [7].

Interestingly, the tyrosine phosphatase, SHP2, that has been demonstrated to increase expression of ACSL4 protein in MA-10 Leydig cells [77], has been shown to promote breast cancer progression [78] and to increase motility of TNBC [79], while inhibition of SHP2 induces a basal-to-luminal transition in breast cancer cells characterized by ER expression, estrogen growth dependency and sensitivity to anti-estrogen therapy [80].

Finally, ACSL4 has been demonstrated to be one of three downstream targets of FOXM1-induced migration in MDA-MB-231 cells [74] as well as a mediator of the tumorigenic role of PADI2 in conferring susceptibility to breast cancer [75].

The very long chain synthetase, SLC27A2 (also known as ACSVL1), a peroxisomal enzyme that activates long-chain fatty acids prior to oxidation, is overexpressed in receptor-positive, luminal subtypes of breast cancer. Silencing of ER in MCF7 cells decreases mRNA expression by 52-fold (Table 3).

\section{FATTY ACID STORAGE AND MOBILIZATION}

Lipid droplets are subcellular organelles that are comprised of a phospholipid monolayer membrane delineating a storage space for fatty acids and cholesterol in the form of triglycerides and cholesterol esters. Data support the hypothesis that lipid droplets play an active role in mediating a variety of inflammatory conditions, including cancer [81]. Nutrient deprivation [82] as well as hypoxia [60], have been shown to induce lipid droplet formation, which in turn increases survival of cancer cells. Included in this organelle are a panoply of proteins with both structural and enzymatic functions. As noted above, both ACSL3 and ACSL4 have been localized to lipid droplets, as has LPIN1 [83]. Lipin 1 (LPIN1) is a phosphatidate phosphatase that catalyzes the conversion of phosphatidic acid to diacylglycerol, the penultimate step in triglyceride synthesis. It also functions as a transcriptional co-activator controlling genes involved in fatty acid oxidation (for review, see [84]). The hypoxia-induced accumulation of lipids in lipid droplets is accompanied by an increase in LPIN1 expression secondary to binding of HIF-1 to the hypoxia response element on the LPIN1 gene promoter, and can be inhibited by silencing the LPIN1 gene [85]. In breast and prostate cancer cell lines, knock down of LPIN1 inhibits proliferation and migration [86]. LPIN1 mRNA is overexpressed in TNBC (Table 1A and 1B), specifically in the basal-like subgroup (Table 2).

Cytosolic PLA2 $\alpha$ (PLA2G4A), has been localized to lipid droplets [87-89] along with its substrate, arachidonoyl phosphatidylcholine [87], and has been demonstrated to play a critical role in lipid droplet formation, although the precise mechanism is unclear [82]. The localization of arachidonic acid-metabolizing enzymes, such as COX-2, to lipid droplets suggests that synthesis of prostaglandins, such as PGE2, might take place in a coordinated manner within the lipid droplet domain [90]. Both PLA2G4A as well as COX-2 (not shown) are over expressed in basallike-TNBC, as well as induced as a result of silencing of ER (Tables 1, 2 and 3).

Mobilization of free fatty acids from triglycerides in lipid droplets is regulated by a class of proteins called perilipins. The perilipins comprise a family of 5 proteins localized to the surface of lipid droplets that regulate access of cellular lipases to stored triglyceride via phosphorylation state $[91,92]$. As such, they play a regulatory role in the cell's ability to utilize the fatty acids stored in triglycerides. Perilipin 1 (PLIN1) is expressed almost exclusively in adipose tissue, although there is a report of its expression in breast cancer [93]. More recently it has been demonstrated that PLIN1 expression is downregulated in breast cancer, and that reduced expression of PLIN1 in ER+ and luminal A subtypes is associated with a poor prognosis and decreased any eventfree overall survival [94]. Exogenous overexpression of PLIN1 in breast cancer cell lines inhibited proliferation, migration, invasion as well as in vivo tumorigenesis in mice [94]. PLIN2 expression, on the other hand, has been associated with increased lipid droplet formation and prolonged breast cancer cell survival in vitro [95]. PLIN2 mRNA is overexpressed in basal-like-TNBC (Tables 1 and 2), and downregulation of ER increases its expression (Table 3). 
For the most part, expression of proteins involved in lipid droplet formation is increased in TNBC and basal-like breast cancers; however, certain proteins present in lipid droplets, such as ACSL3 and PLIN5, are underexpressed in TNBC, suggesting that there are different types of lipid droplets that might function to channel fatty acids to specific metabolic pathways. Along the same lines, mRNA for enzymes that mobilize free fatty acids from triglycerides, including monoglyceride lipase (MGLL) and adipose triglyceride lipase (PNPLA2), appear to be underexpressed in basal-like-TNBC (Tables 1 and 2), suggesting that mobilization of free fatty acids predominates in RNBC. However, expression of MGLL has also been demonstrated to be associated with increased aggressive properties in a variety of cancer cell lines, including breast [96].

\section{FATTY ACID OXIDATION (FAO)}

Although the emphasis with respect to dysregulation of lipid metabolism in cancer has been on lipogenesis and increased expression of lipogenic enzymes such as FASN, it is clear that fatty acid oxidation also plays a role in supporting the malignant phenotype [97]. Fatty acids comprise an efficient source of energy that results in the generation of a large quantity of ATP, and under conditions of nutrient deprivation cancer cell survival depends on FAO [82]. The glucose addiction induced in glioblastoma cells by activation of AKT, for example, can be overcome by activation of FAO [98]. The analysis of the expression of mRNAs associated with fatty acid oxidation as shown in Table 1 suggests that this pathway, like that of de novo fatty acid synthesis, is more active in RPBC than in TNBC. This finding is consistent with the hypothesis of Delgoffe and Powell that utilization of fatty acids as fuel in heavily proliferative cells would interfere with membranogenesis, and therefore fatty acid oxidation would preferentially serve as a source of energy in more quiescent cells [99]. Thus in the less highly proliferative RPBC both fatty acid synthesis and oxidation are enhanced, suggesting a futile cycle. It has further been suggested that this futile cycle might function to maintain mitochondrial integrity [100].

The rate-limiting step in the mitochondrial fatty acid $\beta$-oxidation pathway is the transport of fatty acyl-CoAs into the mitochondria by carnitine palmitoyl transferase 1 (CPT1) proteins. The meta-analyses shown in Tables 1 and 2 indicate that CPT1A mRNA expression levels are higher in RPBC versus TNBC, and predominate in HER2enriched and luminal B subtypes. There are additional data supporting these observations. Immunohistochemical data indicate the predominance of CPT1A protein in HER2enriched breast tumors [41]. Using an integrated genomic strategy, Gatza et al recently identified CPT1A as a genetic driver of proliferation specifically in the luminal subtype of breast cancer [101]. Another isoform, CPT1C, has been determined to promote cell survival and breast tumor growth under conditions of metabolic stress [102]. In addition to its mitochondrial transport activity, CPT1A has also been demonstrated to localize to the nucleus, where it has been shown to bind to HDAC1 [103]. Silencing of CPT1A expression was correlated with increased apoptosis, inhibition of metastasis, a reduction in HDAC1 activity and hyperacetylation of histones [104].

Predomination of CPT1A expression in RPBC, however, does not preclude a role for FAO in TNBC. In fact, treating MYC-overexpressing TNBC with an inhibitor of CPT1A was effective in decreasing energy metabolism in MYC-overexpressing TNBC cells and in blocking tumor growth in a MYC-driven transgenic TNBC model as well as in a MYC-overexpressing patientderived xenograft [16]. And under conditions of chronic acidosis, glucose utilization is decreased as a source of acetyl-CoA, while uptake of exogenous fatty acids and FAO is increased [105].

Fatty acid oxidation can also take place in peroxisomes. Branched chain acyl-CoA oxidase 2 $(\mathrm{ACOX} 2)$ is the rate-limiting enzyme in the $\beta$-oxidation of branched, long-chain fatty acids that takes place in peroxisomes. Expression and translation of a variant transcript, ACOX2-i9, has been demonstrated to be regulated by estrogens in ER-positive breast cancer cells lines, and knock down of this enzyme results in decreased cell viability [106]. Although ACOX2 mRNA is overexpressed in RPBC and luminal subtypes, paradoxically, silencing of ER results in increased expression of ACOX2 mRNA (Table 3).

\section{CONCLUSIONS}

Data summarized here indicate that dysregulation of fatty acid metabolism is essential for maintenance of proliferation and survival of breast cancer cells. To date, potential treatment options have overwhelmingly targeted FASN, and the first-in-human investigation of the oral first-in-class FASN inhibitor, TVB-2640, is currently underway (https://clinicaltrials.gov/show/ NCT02223247); however, several other lipid metabolic enzymes have known inhibitors, some even FDA approved (for a list, see [107]). For example, targeting ACACA has the advantage that, since this enzyme has long been considered a target in the treatment of metabolic diseases, there are a number of inhibitors already available (for review see [108]). Likewise, inhibitors are also available for the rate-limiting enzyme in FAO, CPT1A [109]. One of these inhibitors, ranolazine, has FDA approval. Inhibiting fatty acid activation, on the other hand, has the advantage of blocking both synthesis and oxidation, as well as overcoming the need to inhibit uptake of exogenous fatty acids. Triacsin $\mathrm{C}$ is a fatty acid analogue that has been shown to inhibit ACSL 1, ACSL3 and ACSL4. This compound causes apoptosis of many cancer cell types, including breast [71, 110-113], and has been demonstrated 
to inhibit the growth of xenograft tumors [110]. Lipid droplets comprise an emerging target in a number of diseases, including cancer, and it has been suggested that the lipid droplet protein, PLIN2, might make an effective target [114]. Based on the differential expression of FAM proteins with respect to intrinsic molecular subtype in breast cancer, the design of future studies needs to account for this heterogeneity.

\section{ACKNOWLEDGMENTS}

This work is supported by an award from the Department of Defense, BCRP Idea Award (BC084403) to the author.

\section{CONFLICTS OF INTEREST}

The author declares no conflicts of interest.

\section{REFERENCES}

1. Hu Z, Fan C, Oh DS, Marron JS, He X, Qaqish BF, Livasy C, Carey LA, Reynolds E, Dressler L, Nobel A, Parker $\mathrm{J}$, Ewend MG, et al. The molecular portraits of breast tumors are conserved across microarray platforms. BMC Genomics. 2006; 7: 96-. doi: 10.1186/1471-2164-7-96.

2. Parker JS, Mullins M, Cheang MCU, Leung S, Voduc D, Vickery T, Davies S, Fauron C, He X, Hu Z, Quackenbush JF, Stijleman IJ, Palazzo J, et al. Supervised Risk Predictor of Breast Cancer Based on Intrinsic Subtypes. Journal of Clinical Oncology. 2009; 27: 1160-7. doi: 10.1200/ jco.2008.18.1370.

3. Prat A, Perou CM. Deconstructing the molecular portraits of breast cancer. Molecular Oncology. 2011; 5: 5-23.

4. Prat A, Adamo B, Cheang MCU, Anders CK, Carey LA, Perou CM. Molecular Characterization of BasalLike and Non-Basal-Like Triple-Negative Breast Cancer. The Oncologist. 2013; 18: 123-33. doi: 10.1634/ theoncologist.2012-0397.

5. Lehmann BD, Bauer JA, Chen X, Sanders ME, Chakravarthy AB, Shyr Y, Pietenpol JA. Identification of human triple-negative breast cancer subtypes and preclinical models for selection of targeted therapies. The Journal of Clinical Investigation. 2011; 121: 2750-67.

6. Burstein MD, Tsimelzon A, Poage GM, Covington KR, Contreras A, Fuqua SAW, Savage MI, Osborne CK, Hilsenbeck SG, Chang JC, Mills GB, Lau CC, Brown PH. Comprehensive Genomic Analysis Identifies Novel Subtypes and Targets of Triple-Negative Breast Cancer. Clinical Cancer Research. 2015; 21: 1688-98. doi: 10.1158/1078-0432.ccr-14-0432.

7. Wu X, Li Y, Wang J, Wen X, Marcus MT, Daniels G, Zhang DY, Ye F, Wang LH, Du X, Adams S, Singh B, Zavadil J, et al. Long Chain Fatty Acyl-CoA Synthetase 4 Is a Biomarker for and Mediator of Hormone Resistance in
Human Breast Cancer. PLoS ONE. 2013; 8: e77060. doi: 10.1371/journal.pone.0077060.

8. Hon JDC, Singh B, Sahin A, Du G, Wang J, Wang VY, Deng FM, Zhang DY, Monaco ME, Lee P. Breast cancer molecular subtypes: from TNBC to QNBC. American Journal of Cancer Research. 2016; 6: 1864-72.

9. Rhodes DR, Yu J, Shanker K, Deshpande N, Varambally R, Ghosh D, Barrette T, Pandey T, Chinnaiyan AM. Oncomine: A cancer microarray database and integrated data-mining platform. Neoplasia. 2004; 6: 1-6.

10. Chin K, DeVries S, Fridlyand J, Spellman PT, Roydasgupta R, Kuo WL, Lapuk A, Neve RM, Qian Z, Ryder T, Chen F, Feiler H, Tokuyasu T, et al. Genomic and transcriptional aberrations linked to breast cancer pathophysiologies. Cancer Cell. 2006; 10: 529-41.

11. Curtis C, Shah SP, Chin SF, Turashvili G, Rueda OM, Dunning MJ, Speed D, Lynch AG, Samarajiwa S, Yuan Y, Graf S, Ha G, Haffari G, et al. The genomic and transcriptomic architecture of 2,000 breast tumours reveals novel subgroups. Nature. 2012; 486: 346-52.

12. Hatzis C, Pusztai L, Valero V, Booser DJ, Esserman L, Lluch A, Vidaurre T, Holmes F, Souchon E, Wang H, Martin M, Cotrina J, Gomez H, et al. A genomic predictor of response and survival following taxane-anthracycline chemotherapy for invasive breast cancer. JAMA. 2011; 305: 1873-81. doi: 10.1001/jama.2011.593.

13. Richardson AL, Wang ZC, De Nicolo A, Lu X, Brown M, Miron A, Liao X, Iglehart JD, Livingston DM, Ganesan S. $\mathrm{X}$ chromosomal abnormalities in basal-like human breast cancer. Cancer Cell. 2006; 9: 121-32.

14. Network TCGA. Comprehensive molecular portraits of human breast tumours. Nature. 2012; 490: 61-70.

15. Neve RM, Chin K, Fridlyand J, Yeh J, Baehner FL, Fevr T, Clark L, Bayani N, Coppe JP, Tong F, Speed T, Spellman PT, DeVries S, et al. A collection of breast cancer cell lines for the study of functionally distinct cancer subtypes. Cancer Cell. 2006; 10: 515-27.

16. Camarda R, Zhou AY, Kohnz RA, Balakrishnan S, Mahieu C, Anderton B, Eyob H, Kajimura S, Tward A, Krings G, Nomura DK, Goga A. Inhibition of fatty acid oxidation as a therapy for MYC-overexpressing triple-negative breast cancer. Nat Med. 2016; 22: 427-32.

17. Anderson E, Clarke RB. Steroid Receptors and Cell Cycle in Normal Mammary Epithelium. Journal of Mammary Gland Biology and Neoplasia. 2004; 9: 3-13. doi: 10.1023/b:jo mg.0000023584.01750.16.

18. Prat A, Karginova O, Parker J, Fan C, He X, Bixby L, Harrell JC, Roman E, Adamo B, Troester M, Perou C. Characterization of cell lines derived from breast cancers and normal mammary tissues for the study of the intrinsic molecular subtypes. Breast Cancer Research and Treatment. 2013: 1-19. doi: 10.1007/s10549-013-2743-3.

19. Prat A, Parker JS, Fan C, Perou CM. PAM50 assay and the three-gene model for identifying the major and clinically 
relevant molecular subtypes of breast cancer. Breast Cancer Research and Treatment. 2012; 135: 301-6.

20. Esserman LJ, Berry DA, Cheang MCU, Yau C, Perou CM, Carey L, DeMichele A, Gray JW, Conway-Dorsey K, Lenburg ME, Buxton MB, Davis SE, van't Veer LJ, et al. Chemotherapy response and recurrence-free survival in neoadjuvant breast cancer depends on biomarker profiles: results from the I-SPY 1 TRIAL (CALGB 150007/150012; ACRIN 6657). Breast Cancer Research and Treatment. 2012; 132: 1049-62. doi: 10.1007/s10549-011-1895-2.

21. Al Saleh S, Al Mulla F, Luqmani YA. Estrogen Receptor Silencing Induces Epithelial to Mesenchymal Transition in Human Breast Cancer Cells. PLoS ONE. 2011; 6: e20610.

22. Weiss L, Hoffman G, Schreiber R, Andres H, Fuchs E, Korber E, Kolb H. Fatty-acid biosynthesis in man, a pathway of minor importance. Purification, optimal assay conditions, and organ distribution of fatty-acid synthase. Biol Chem Hoppe Seyler. 1986; 367: 905-12.

23. Zaidi N, Swinnen JV, Smans K. ATP-Citrate Lyase: A Key Player in Cancer Metabolism. Cancer Research. 2012; 72: 3709-14. doi: 10.1158/0008-5472.can-11-4112.

24. Szutowicz A, Kwiatkowski J, Angielski S. Lipogenetic and glycolytic enzyme activities in carcinoma and nonmalignant diseases of the human breast. British Journal of Cancer. 1979; 39: 681-7.

25. Hatzivassiliou G, Zhao F, Bauer DE, Andreadis C, Shaw AN, Dhanak D, Hingorani SR, Tuveson DA, Thompson CB. ATP citrate lyase inhibition can suppress tumor cell growth. Cancer Cell. 2005; 8: 311-21.

26. Steeg PS, Horak CE, Miller KD. Clinical-Translational Approaches to the Nm23-H1 Metastasis Suppressor. Clinical Cancer Research. 2008; 14: 5006-12. doi: 10.1158/1078-0432.ccr-08-0238.

27. Lucenay KS, Doostan I, Karakas C, Bui T, Ding Z, Mills GB, Hunt KK, Keyomarsi K. Cyclin E associates with the lipogenic enzyme ATP-citrate lyase to enable malignant growth of breast cancer cells. Cancer Research. 2016.

28. Milgraum LZ, Witters LA, Pasternack GR, Kuhajda FP. Enzymes of the fatty acid synthesis pathway are highly expressed in in situ breast carcinoma. Clin Cancer Res. 1997; 3: 2115-20.

29. Chajes V, Cambot M, Moreau K, Lenoir GM, Joulin V. Acetyl-CoA Carboxylase \{alpha\} Is Essential to Breast Cancer Cell Survival. Cancer Res. 2006; 66: 5287-94. doi: 10.1158/0008-5472.can-05-1489.

30. Yoon S, Lee MY, Park SW, Moon JS, Koh YK, Ahn YH, Park BW, Kim KS. Up-regulation of Acetyl-CoA Carboxylase \{alpha\} and Fatty Acid Synthase by Human Epidermal Growth Factor Receptor 2 at the Translational Level in Breast Cancer Cells. J Biol Chem. 2007; 282: 26122-31. doi: 10.1074/jbc.M702854200.

31. Corominas-Faja B, Cuyàs E, Gumuzio J, Bosch-Barrera J, Leis O, Martin ÁG, Menendez JA. Chemical inhibition of acetyl-CoA carboxylase suppresses self-renewal growth of cancer stem cells. Oncotarget. 2014; 5: 8306-16. doi: 10.18632/oncotarget.2059.

32. Menendez JA, Lupu R. Fatty acid synthase and the lipogenic phenotype in cancer pathogenesis. Nat Rev Cancer. 2007; 7: 763-77.

33. Little J, Kridel S. Fatty acid synthase activity in tumor cells. Subcellular Biochemistry. 2008; 49: 169-94.

34. Young C, Anderson S. Sugar and fat - that's where it's at: metabolic changes in tumors. Breast Cancer Research. 2008; 10: 202-10.

35. Furuta E, Okuda H, Kobayashi A, Watabe K. Metabolic genes in cancer: Their roles in tumor progression and clinical implications. Biochimica et Biophysica Acta (BBA) - Reviews on Cancer. 2010; 1805: 141-52.

36. Kuhajda FP. Fatty Acid Synthase and Cancer: New Application of an Old Pathway. Cancer Res. 2006; 66: 5977-80. doi: 10.1158/0008-5472.can-05-4673.

37. Yang YA, Han WF, Morin PJ, Chrest FJ, Pizer ES. Activation of Fatty Acid Synthesis during Neoplastic Transformation: Role of Mitogen-Activated Protein Kinase and Phosphatidylinositol 3-Kinase. Experimental Cell Research. 2002; 279: 80-90.

38. Kumar-Sinha C, Ignatoski KW, Lippman ME, Ethier SP, Chinnaiyan AM. Transcriptome Analysis of HER2 Reveals a Molecular Connection to Fatty Acid Synthesis. Cancer Res. 2003; 63: 132-9.

39. Jin Q, Yuan L, Boulbes D, Baek JM, Wang YN, GomezCabello D, Hawke D, Yeung SC, Lee MH, Hortobagyi G, Hung MC, Esteva F. Fatty acid synthase phosphorylation: a novel therapeutic target in HER2-overexpressing breast cancer cells. Breast Cancer Research. 2010; 12: R96.

40. Vazquez-Martin A, Colomer R, Brunet J, Lupu R, Menendez JA. Overexpression of fatty acid synthase gene activates HER1/HER2 tyrosine kinase receptors in human breast epithelial cells. Cell Proliferation. 2008; 41: 59-85. doi: 10.1111/j.1365-2184.2007.00498.x.

41. Kim S, Lee Y, Koo JS. Differential Expression of Lipid Metabolism-Related Proteins in Different Breast Cancer Subtypes. PLoS ONE. 2015; 10: e0119473. doi: 10.1371/ journal.pone.0119473.

42. Ntambi JM, Miyazaki M. Regulation of stearoyl-CoA desaturases and role in metabolism. Progress in Lipid Research. 2004; 43: 91-104.

43. Zhang L, Ge L, Parimoo S, Stenn K, Prouty SM. Human stearoyl-CoA desaturase: alternative transcripts generated from a single gene by usage of tandem polyadenylation sites. Biochem J. 1999; 340: 255-64.

44. Wang J, Yu L, Schmidt RE, Su C, Huang X, Gould K, Cao G. Characterization of HSCD5, a novel human stearoylCoA desaturase unique to primates. Biochemical and Biophysical Research Communications. 2005; 332: 735-42.

45. Igal RA. Stearoyl-CoA desaturase-1: a novel key player in the mechanisms of cell proliferation, programmed cell death and transformation to cancer. Carcinogenesis. 2010; 
31: 1509-15. doi: 10.1093/carcin/bgq131.

46. Rueda-Rincon N, Bloch K, Derua R, Vyas R, Harms A, Hankemeier T, Ali Khan N, Dehairs J, Bagadi M, Mercedes Binda M, Waelkens E, Marine JC, Swinnen JV. p53 attenuates AKT signaling by modulating membrane phospholipid composition. 2015. 2015; 6: 21240-54.

47. Kumar-Sinha C, Ignatoski KW, Lippman ME, Ethier SP, Chinnaiyan AM. Transcriptome analysis of HER2 reveals a molecular connection to fatty acid synthesis. Cancer Research. 2003; 63: 132-9.

48. Pitroda SP, Khodarev NN, Beckett MA, Kufe DW, Weichselbaum RR. MUC1-induced alterations in a lipid metabolic gene network predict response of human breast cancers to tamoxifen treatment. Proceedings of the National Academy of Sciences, USA. 2009; 106: 5837-41.

49. Belkaid A, Duguay SR, Ouellette RJ, Surette ME. $17 \beta$-estradiol induces stearoyl-CoA desaturase-1 expression in estrogen receptor-positive breast cancer cells. BMC Cancer. 2015; 15: 440. doi: 10.1186/s12885-015-1452-1.

50. Scaglia N, Chisholm JW, Igal RA. Inhibition of StearoylCoA Desaturase-1 Inactivates Acetyl-CoA Carboxylase and Impairs Proliferation in Cancer Cells: Role of AMPK. PLoS ONE. 2009; 4: e6812.

51. Nieman KM, Romero IL, Van Houten B, Lengyel E. Adipose tissue and adipocytes support tumorigenesis and metastasis. Biochimica et Biophysica Acta (BBA) Molecular and Cell Biology of Lipids. 2013; 1831: 153341. doi: 10.1016/j.bbalip.2013.02.010.

52. Zaidi N, Lupien L, Kuemmerle NB, Kinlaw WB, Swinnen JV, Smans K. Lipogenesis and lipolysis: The pathways exploited by the cancer cells to acquire fatty acids. Progress in Lipid Research. 2013; 52: 585-9. doi: 10.1016/j. plipres.2013.08.005.

53. Kuemmerle NB, Rysman E, Lombardo PS, Flanagan AJ, Lipe BC, Wells WA, Pettus JR, Froehlich HM, Memoli VA, Morganelli PM, Swinnen JV, Timmerman LA, Chaychi L, et al. Lipoprotein Lipase Links Dietary Fat to Solid Tumor Cell Proliferation. Molecular Cancer Therapeutics. 2011; 10: 427-36. doi: 10.1158/1535-7163.mct-10-0802.

54. He L, Lu Y, Wang P, Zhang J, Yin C, Qu S. Up-regulated expression of type II very low density lipoprotein receptor correlates with cancer metastasis and has a potential link to $\beta$-catenin in different cancers. BMC Cancer. 2010; 10: 601-. doi: 10.1186/1471-2407-10-601.

55. Thumser AE, Moore JB, Plant NJ. Fatty acid binding proteins: tissue-specific functions in health and disease. Current Opinion in Clinical Nutrition \& Metabolic Care. 2014; 17: 124-9. doi: 10.1097/mco.0000000000000031.

56. Liu RZ, Graham K, Glubrecht DD, Germain DR, Mackey JR, Godbout R. Association of FABP5 Expression With Poor Survival in Triple-Negative Breast Cancer: Implication for Retinoic Acid Therapy. The American Journal of Pathology. 2011; 178: 997-1008.

57. Tang XY, Umemura S, Tsukamoto H, Kumaki N, Tokuda
Y, Osamura RY. Overexpression of fatty acid binding protein-7 correlates with basal-like subtype of breast cancer. Pathology - Research and Practice. 2010; 206: 98-101.

58. Liu RZ, Graham K, Glubrecht DD, Lai R, Mackey JR, Godbout R. A fatty acid-binding protein $7 / \mathrm{RXR} \beta$ pathway enhances survival and proliferation in triple-negative breast cancer. The Journal of Pathology. 2012; 228: 310-21. doi: 10.1002/path.4001.

59. Levi L, Lobo G, Doud MK, von Lintig J, Seachrist D, Tochtrop GP, Noy N. Genetic ablation of the fatty acid binding protein FABP5 suppresses HER2-induced mammary tumorigenesis. Cancer research. 2013; 73: 477080. doi: 10.1158/0008-5472.CAN-13-0384.

60. Bensaad K, Favaro E, Lewis Caroline A, Peck B, Lord S, Collins Jennifer M, Pinnick Katherine E, Wigfield S, Buffa Francesca M, Li JL, Zhang Q, Wakelam Michael JO, Karpe F, et al. Fatty Acid Uptake and Lipid Storage Induced by HIF-1 $\alpha$ Contribute to Cell Growth and Survival after Hypoxia-Reoxygenation. Cell Reports. 2014; 9: 349-65. doi: 10.1016/j.celrep.2014.08.056.

61. Maloberti PM, Duarte AB, Orlando UD, Pasqualini ME, Solano ÅR, Lopez-Otin C, Podesta EJ. Functional Interaction between Acyl-CoA Synthetase 4, Lipooxygenases and Cyclooxygenase-2 in the Aggressive Phenotype of Breast Cancer Cells. PLoS ONE. 2010; 5: e15540.

62. Golej DL, Askari B, Kramer F, Barnhart S, VivekanandanGiri A, Pennathur S, Bornfeldt KE. Long-chain acyl-CoA synthetase 4 modulates prostaglandin E2 release from human arterial smooth muscle cells. Journal of Lipid Research. 2011; 52: 782-93. doi: 10.1194/jlr.M013292.

63. Coleman RA, Lee DP. Enzymes of triacylglycerol synthesis and their regulation. Prog Lipid Res. 2004; 43: 134-76. doi:

64. Mashima T, Sato S, Okabe S, Miyata S, Matsuura M, Sugimoto Y, Tsuruo T, Seimiya H. Acyl-CoA synthetase as a cancer survival factor: its inhibition enhances the efficacy of etoposide. Cancer Science. 2009; 100: 1556-62.

65. Stern W, Pullman ME. Acyl-CoA:sn-glycerol-3-phosphate acyltransferase and the positional distribution of fatty acids in phospholipids of cultured cells. J Biol Chem. 1978; 253: 8047-55.

66. Lewin TM, Van Horn CG, Krisans SK, Coleman RA. Rat liver acyl-CoA synthetase 4 is a peripheral-membrane protein located in two distinct subcellular organelles, peroxisomes, and mitochondrial-associated membrane. Archives of Biochemistry and Biophysics. 2002; 404: 26370.

67. Brasaemle DL, Dolios G, Shapiro L, Wang R. Proteomic Analysis of Proteins Associated with Lipid Droplets of Basal and Lipolytically Stimulated 3T3-L1 Adipocytes. Journal of Biological Chemistry. 2004; 279: 46835-42. doi: 10.1074/jbc.M409340200.

68. Sung KY, Hwang SY, Park MK, Bae HI, Kim WH, Kim JC, Kim M. Fatty acid-CoA ligase 4 is overexpressed in human 
hepatocellular carcinoma. Cancer Science. 2003; 94: 421-4.

69. Liang YC, Wu CH, Chu JS, Wang CK, Hung LF, Wang YJ, Ho YS, Chang JG, Lin SY. Involvement of fatty acid-CoA ligase 4 in hepatocellular carcinoma growth: roles of cyclic AMP and p38 mitogen-activated protein kinase. World JGastroenterol. 2005; 11: 2557-63.

70. Cao Y, Dave KB, Doan TP, Prescott SM. Fatty acid CoA ligase 4 is up-regulated in colon adenocarcinoma. Cancer Research. 2001; 61: 8429-34.

71. Monaco ME, Creighton CJ, Lee P, Zou X, Topham MK, Stafforini DM. Expression of Long-chain Fatty Acyl-CoA Synthetase 4 in Breast and Prostate Cancers Is Associated with Sex Steroid Hormone Receptor Negativity. Transl Oncol. 2010; 3: 91-8.

72. Orlando UD, Garona J, Ripoll GV, Maloberti PM, Solano AR, Avagnina A, Gomez DE, Alonso DF, Podesta EJ. The Functional Interaction between Acyl-CoA Synthetase 4, 5-Lipooxygenase and Cyclooxygenase-2 Controls Tumor Growth: A Novel Therapeutic Target. PLoS ONE. 2012; 7: e40794.

73. Orlando UD, Castillo AF, Dattilo MA, Solano AR, Maloberti PM, Podesta EJ. Acyl-CoA synthetase-4, a new regulator of $\mathrm{mTOR}$ and a potential therapeutic target for enhanced estrogen receptor function in receptor-positive and -negative breast cancer. Oncotarget. 2015; 6: 4263250. doi: 10.18632/oncotarget.5822.

74. Ye X, Zhang Y, He B, Meng Y, Li Y, Gao Y. Quantitative proteomic analysis identifies new effectors of FOXM1 involved in breast cancer cell migration. International Journal of Clinical and Experimental Pathology. 2015; 8: 15836-44.

75. Wang H, Xu B, Zhang X, Zheng Y, Zhao Y, Chang X. PADI2 gene confers susceptibility to breast cancer and plays tumorigenic role via ACSL4, BINC3 and CA9 signaling. Cancer Cell International. 2016; 16: 1-12. doi: 10.1186/s12935-016-0335-0.

76. Castillo AF, Orlando UD, Lopez P, Solano AR, Maloberti PM, Podesta EJ. Gene expression profile and signalling pathways in MCF-7 breast cancer cells mediated by AcylCoa synthetase 4 overexpression. Transcriptomics. 2015; 3 . doi: 10.4172/2329-8936.1000120.

77. Cooke M, Orlando U, Maloberti P, Podesta EJ, Cornejo Maciel F. Tyrosine phosphatase SHP2 regulates the expression of acyl-CoA synthetase ACSL4. Journal of Lipid Research. 2011; 52: 1936-48. doi: 10.1194/jlr.M015552.

78. Aceto N, Sausgruber N, Brinkhaus H, Gaidatzis D, MartinyBaron G, Mazzarol G, Confalonieri S, Quarto M, Hu G, Balwierz PJ, Pachkov M, Elledge SJ, van Nimwegen $\mathrm{E}$, et al. Tyrosine phosphatase SHP2 promotes breast cancer progression and maintains tumor-initiating cells via activation of key transcription factors and a positive feedback signaling loop. Nat Med. 2012; 18: 529-37.

79. Sausgruber N, Coissieux MM, Britschgi A, Wyckoff J, Aceto N, Leroy C, Stadler MB, Voshol H, Bonenfant D,
Bentires-Alj M. Tyrosine phosphatase SHP2 increases cell motility in triple-negative breast cancer through the activation of SRC-family kinases. Oncogene. 2015; 34: 2272-8. doi: 10.1038/onc.2014.170.

80. Zhao H, Agazie YM. Inhibition of SHP2 in basal-like and triple-negative breast cells induces basal-to-luminal transition, hormone dependency, and sensitivity to antihormone treatment. BMC Cancer. 2015; 15: 109.

81. Bozza PT, Viola JPB. Lipid droplets in inflammation and cancer. Prostaglandins, Leukotrienes and Essential Fatty Acids (PLEFA). 2010; 82: 243-50.

82. Cabodevilla AG, Sanchez-Caballero L, Nintou E, Boiadjieva VG, Picatoste F, Gubern A, Claro E. Cell Survival during Complete Nutrient Deprivation Depends on Lipid Droplet-fueled beta-Oxidation of Fatty Acids. Journal of Biological Chemistry. 2013; 288: 27777-88. doi: 10.1074/jbc.M113.466656.

83. Valdearcos M, Esquinas E, Meana C, Gil-de-Gómez L, Guijas C, Balsinde J, Balboa MA. Subcellular Localization and Role of Lipin-1 in Human Macrophages. The Journal of Immunology. 2011; 186: 6004-13. doi: 10.4049/ jimmunol.1003279.

84. Chen Y, Rui BB, Tang LY, Hu CM. Lipin Family Proteins - Key Regulators in Lipid Metabolism. Annals of Nutrition and Metabolism. 2015; 66: 10-8.

85. Mylonis I, Sembongi H, Befani C, Liakos P, Siniossoglou $\mathrm{S}$, Simos G. Hypoxia causes triglyceride accumulation by HIF-1-mediated stimulation of lipin 1 expression. Journal of Cell Science. 2012; 125: 3485-93. doi: 10.1242/jcs.106682.

86. Brohée L, Demine S, Willems J, Arnould T, Colige AC, Deroanne CF. Lipin-1 regulates cancer cell phenotype and is a potential target to potentiate rapamycin treatment. Oncotarget. 2015; 6: 11264-80. doi: 10.18632/ oncotarget.3595.

87. Yu W, Bozza PT, Tzizik DM, Gray JP, Cassara J, Dvorak AM, Weller PF. Co-compartmentalization of MAP kinases and cytosolic phospholipase A2 at cytoplasmic arachidonate-rich lipid bodies. The American Journal of Pathology. 1998; 152: 759-69.

88. Khatchadourian A, Bourque SD, Richard VR, Titorenko VI, Maysinger D. Dynamics and regulation of lipid droplet formation in lipopolysaccharide (LPS)-stimulated microglia. Biochimica et Biophysica Acta (BBA) Molecular and Cell Biology of Lipids. 2012; 1821: 607-17.

89. Moreira LS, Piva B, Gentile LB, Mesquita-Santos FP, D'Avila H, Maya-Monteiro CM, Bozza PT, Bandeira-Melo C, Diaz BL. Cytosolic phospholipase A2-driven PGE2 synthesis within unsaturated fatty acids-induced lipid bodies of epithelial cells. Biochimica et Biophysica Acta (BBA) Molecular and Cell Biology of Lipids. 2009; 1791: 156-65.

90. Accioly MT, Pacheco P, Maya-Monteiro CM, Carrossini N, Robbs BK, Oliveira SS, Kaufmann C, Morgado-Diaz JA, Bozza PT, Viola JPB. Lipid bodies are reservoirs of cyclooxygenase-2 and sites of prostaglandin-E2 synthesis 
in colon cancer cells. Cancer Research. 2008; 68: 1732-40.

91. Sztalryd C, Kimmel AR. Perilipins: Lipid droplet coat proteins adapted for tissue-specific energy storage and utilization, and lipid cytoprotection. Biochimie. 2013.

92. Bickel PE, Tansey JT, Welte MA. PAT proteins, an ancient family of lipid droplet proteins that regulate cellular lipid stores. Biochimica et Biophysica Acta (BBA) - Molecular and Cell Biology of Lipids. 2009; 1791: 419-40.

93. Harvell DE, Spoelstra N, Singh M, McManaman J, Finlayson C, Phang T, Trapp S, Hunter L, Dye W, Borges V, Elias A, Horwitz K, Richer J. Molecular signatures of neoadjuvant endocrine therapy for breast cancer: characteristics of response or intrinsic resistance. Breast Cancer Research and Treatment. 2008; 112: 475-88. doi: 10.1007/s10549-008-9897-4.

94. Zhou C, Wang M, Zhou L, Zhang Y, Liu W, Qin W, He R, Lu Y, Wang Y, Chen XZ, Tang J. Prognostic significance of PLIN1 expression in human breast cancer. Oncotarget. 2016; 7:54488-54502. doi: 10.18632/oncotarget.10239.

95. Pucer A, Brglez V, Payre C, Pungerar J, Lambeau G, Petan T. Group X secreted phospholipase A2 induces lipid droplet formation and prolongs breast cancer cell survival. Molecular Cancer. 2013; 12: 111.

96. Nomura DK, Long JZ, Niessen S, Hoover HS, Ng SW, Cravatt BF. Monoacylglycerol Lipase Regulates a Fatty Acid Network that Promotes Cancer Pathogenesis. Cell. 2010; 140: 49-61. doi: 10.1016/j.cell.2009.11.027.

97. Carracedo A, Cantley LC, Pandolfi PP. Cancer metabolism: fatty acid oxidation in the limelight. Nat Rev Cancer. 2013; 13: 227-32.

98. Buzzai M, Bauer DE, Jones RG, DeBerardinis RJ, Hatzivassiliou G, Elstrom RL, Thompson CB. The glucose dependence of Akt-transformed cells can be reversed by pharmacologic activation of fatty acid [beta]-oxidation. Oncogene. 2005; 24: 4165-73.

99. Delgoffe GM, Powell JD. Sugar, fat, and protein: new insights into what $\mathrm{T}$ cells crave. Current Opinion in Immunology. 2015; 33: 49-54.

100. O'Sullivan D, van der Windt GJW, Ching-Cheng Huang S, Curtis JD, Chang CH, Buck MD, Qiu J, Smith AM, Lam WY, DiPlato LM, Hsu FF, Birnbaum MJ, Pearce EJ, et al. Memory CD8(+) T cells use cell intrinsic lipolysis to support the metabolic programming necessary for development. Immunity. 2014; 41: 75-88. doi: 10.1016/j. immuni.2014.06.005.

101. Gatza ML, Silva GO, Parker JS, Fan C, Perou CM. An integrated genomics approach identifies drivers of proliferation in luminal-subtype human breast cancer. Nat Genet. 2014; 46: 1051-9.

102. Zaugg K, Yao Y, Reilly PT, Kannan K, Kiarash R, Mason J, Huang P, Sawyer SK, Fuerth B, Faubert B, Kalliomäki $\mathrm{T}$, Elia A, Luo X, et al. Carnitine palmitoyltransferase $1 \mathrm{C}$ promotes cell survival and tumor growth under conditions of metabolic stress. Genes \& Development. 2011; 25: 1041-
51. doi: 10.1101/gad.1987211.

103. Mazzarelli P, Pucci S, Bonanno E, Sesti F, Calvani M, Giusto Spagnoli L. Carnitine palmitoyltransferase I in human carcinomas: A novel role in histone deacetylation? Cancer Biology \& Therapy. 2007; 6: 1606-13.

104. Pucci S, Zonetti MJ, Fisco T, Polidoro C, Bocchinfuso G, Palleschi A, Novelli G, Spagnoli LG, Mazzarelli P. Carnitine palmitoyl transferase-1A (CPT1A): a new tumor specific target in human breast cancer. Oncotarget. 2016; 7 : 19982-96. doi: 10.18632/oncotarget.6964.

105. Corbet C, Pinto A, Martherus R, Santiago de Jesus João P, Polet F, Feron O. Acidosis Drives the Reprogramming of Fatty Acid Metabolism in Cancer Cells through Changes in Mitochondrial and Histone Acetylation. Cell Metabolism. 2016; 24: 311-23. doi: 10.1016/j.cmet.2016.07.003.

106. Bjørklund SS, Kristensen VN, Seiler M, Kumar S, Alnæs GIG, Ming Y, Kerrigan J, Naume B, Sachidanandam R, Bhanot G, Børresen-Dale AL, Ganesan S. Expression of an estrogen-regulated variant transcript of the peroxisomal branched chain fatty acid oxidase ACOX2 in breast carcinomas. BMC Cancer. 2015; 15: 524. doi: 10.1186/ s12885-015-1510-8.

107. Currie E, Schulze A, Zechner R, Walther Tobias C, Farese Jr Robert V. Cellular Fatty Acid Metabolism and Cancer. Cell Metabolism. 2013; 18: 153-61.

108. Wang C, Rajput S, Watabe K, Liao DF, Cao D. Acetyl-CoA carboxylase-a as a novel target for cancer therapy. Frontiers in Bioscience. 2010; 2: 515-26.

109. Samudio I, Harmancey R, Fiegl M, Kantarjian H, Konopleva M, Korchin B, Kaluarachchi K, Bornmann W, Duvvuri S, Taegtmeyer H, Andreeff M. Pharmacologic inhibition of fatty acid oxidation sensitizes human leukemia cells to apoptosis induction. The Journal of Clinical Investigation. 2010; 120: 142-56. doi: 10.1172/jci38942.

110. Mashima T, Oh-hara T, Sato S, Mochizuki M, Sugimoto Y, Yamazaki K, Hamada J-i, Tada M, Moriuchi T, Ishikawa Y, Kato Y, Tomoda H, Yamori T, et al. p53-Defective Tumors With a Functional Apoptosome-Mediated Pathway: A New Therapeutic Target. J Natl Cancer Inst. 2005; 97: 765-77. doi: 10.1093/jnci/dji133.

111. Mashima T, Tsuruo T. Defects of the apoptotic pathway as therapeutic target against cancer. Drug Resistance Updates. 2005; 8: 339-43.

112. Mashima T, Seimiya H, Tsuruo T. De novo fatty-acid synthesis and related pathways as molecular targets for cancer therapy. Br J Cancer. 2009; 100: 1369-72.

113. Nuwayhid SJ, Vega M, Walden PD, Monaco ME. Regulation of de novo phosphatidylinositol synthesis. J Lipid Res. 2006; 47: 1449-56. doi: 10.1194/jlr.M600077JLR200.

114. Conte M, Franceschi C, Sandri M, Salvioli S. Perilipin 2 and Age-Related Metabolic Diseases: A New Perspective. Trends in Endocrinology \& Metabolism. 2016; doi: 10.1016/j.tem.2016.09.001. 